\title{
Euratom Reprieved at Dawn
}

Aт a fourteen-hour meeting that ended at 6 o'clock on Tuesday morning the nine science ministers of the European community finally agreed a four-year programme for Euratom.

The three-part agreement, which will cost a total of 160 million units of account (about $£ 66$ million), puts an end to the five years of uncertainty about Euratom's future.

The compromise agreement will save the jobs of 1,650 of the staff of the four joint research laboratories at Ispra in Italy, Karlsruhe in West Germany, Geel in Belgium and Petten in Holland, the last of which was under threat of closure.

The four-year formula provides that 140 million units of account will be spent on a common programme of advanced technology projects ranging from environmental work to applied data processing and reactor safety.

Although this programme is common, not all nations will participate in all parts of the project. Work on the Petten high flux reactor will be shared between Holland, Belgium and West Germany only, France will not be involved in work on the control of fissile materials and Italy will not contribute to research on plutonium at Karlsruhe. Otherwise the programmes in this part of the package are common. In all 1,440 staff will be employed on the first part of the settlement.

The second part of the package has an agreed budget of 20 million units of account and will provide work for a further 209 staff, but the precise research to be undertaken has not yet been agreed. About a dozen projects have been put forward by the commission under this heading, and the nine nations have to agree by May which of these they will support. Ispra's work on the use of hydrogen to generate energy is one of these optional projects.

The third part of the package is labelled "indirect action programmes" and deals with contributions that Euratom will make to various national research projects in the enlarged community. These also will be decided by the end of April and a number of Euratom staff will be seconded to national laboratories, a move that will help reduce redundancies.

The second part of the formula will be reviewed annually and the first part after two years, thus providing at least a measure of security for the $1,948 \mathrm{staff}$ of Euratom, many of whom were threaten- ing to stage a "work-in" on the lines of the Upper Clyde Shipbuilders unions if agreement on a realistic programme was not reached.

As it is, 98 of Euratom's scientists and administrative staff will be made redundant. Forty-eight of these will go because the programme has been cut from the five-year agreement that the commission wanted instituted; the remainder will make way for staff from Britain, Ireland and Denmark who only became part of Euratom in January.

The final programme is evidently something of a compromise between the commission's plans--which would have produced a budget of 185 million units of account-and the views of Britain, Holland and France who were eager that Euratom should be pruned down.

Reactions from the ministers concerned were those of relief as they ended their lengthy meeting. The Belgian science minister, $\mathrm{Mr}$ Charles Hanin, said, "it has been a good night and we are at last emerging from a situation which has lasted many years". Mr Ralf Dahrendorf, the commission member who now has the unenviable task of actually putting the agreement into effect, was slightly more cautious. "This is a sort of turning point", he said.

NUCLEAR POWER

\section{Vinter Report : Select Commiliee Acts}

THE Select Committee on Science and Technology is to invite $\mathrm{Mr}$ Tom Boardman, Minister for Industry, to appear before it with a copy of the Vinter report to explain why the report cannot be published.

Officially known as the thermal reactor review and compiled under the chairmanship of $\mathrm{Mr}$ Peter Vinter, deputy secretary at the Department of Trade and Industry, the report is intended to help ministers decide which type of reactor should be built next.

The Select Committee, which has been examining the nuclear power industry for some months, has repeatedly asked that the report be published. Now it has attempted to use its right to send for "persons, papers and records", as the government has refused to part with a copy.

The committee-which last year published the Docksey report which the government had refused to make public -believes that there is an important principle at stake. It is quite willing to respect the commercial secrets in the Vinter report that the government has repeatedly cited as its reason for not publishing, but it feels that the government's refusal to divulge the thinking that lies behind the report is obstructing the committee in its work.

Mr Arthur Palmer, chairman of the subcommittee that is examining the nuclear power industry, made the point forcefully when the committee was taking evidence from the United Kingdom Atomic Energy Authority last week. On hearing from Mr F. J. Doggett, deputy chairman of the authority, that the authority knew of the Vinter report's contents, he rejoined that he hoped people would note that a public corporation has information that has not yet been made available to Parliament.

Mr Doggett, questioned on the reorganization of the nuclear industry that the government has promised, said that one of the first tasks of the new company will be to establish links with a European company. The new company, he said, "should be left free to choose the best common partnership".

Mr Doggett's emphasis on European links reflected the views of Sir Edwin MacAlpine, chairman of the Nuclear Power Group, when he gave evidence to the select committee recently. Sir Edwin was also at pains to urge that the new company "should be free from any influence of manufacturers"-a remark that was taken to be a thinlyveiled reference to the government's apparent intention to install Sir Arnold Weinstock, managing director of GEC, at the helm of the new company. GEC supplies turbogenerators and other equipment for some nuclear contracts. Sir Edwin made it clear that he favoured a new company made up of three parts-his consortium, the Atomic Energy Authority, and the other consortium, British Nuclear Design and Construction, of which GEC is a part. The government, however, is believed to favour a company with strong central management rather than a merging of the consortia on the lines proposed by Sir Edwin. Sir Edwin, however, told the committee that as far as hopes for a European company go, it "would be a terrible disaster if any one company were seen to be in control". 